\title{
Environmental and human health risks associated with exposure to hazardous elements present in urban dust from Barranquilla, Colombian Caribbean
}

Jorge Osorio-Martinez Luis F. O. Silva Erico M. M. Flores Mariele S. Nascimento Rochele S. Picoloto Jesus Olivero-Verbel

\section{Abstract}

Urban dust is a mixture of deposited particles from different sources usually linked to potentially toxic elements (PTEs). Despite the industrialization of many South American countries, little is known about the impact of particulate matter in large cities, data necessary to promote environmental policies aiming to protect human health. The main objective of this work was to evaluate the particle size distribution, composition, as well as environmental and human health risks of settled dust particles from Barranquilla, a Colombian Caribbean industrialized area. Trace elements were analyzed by ICPMS from thirty-five different sites, covering all city areas. Dust was mostly composed of $10-70 \mu \mathrm{m}$ particles. The average concentrations of $\mathrm{V}, \mathrm{Cr}, \mathrm{Mn}, \mathrm{Co}, \mathrm{Ni}, \mathrm{Cu}, \mathrm{Zn}$, As, Se, Mo, Ag, Cd, Sn, Sb, Pb, and Bi were above background. High spatial heterogeneity was observed for $\mathrm{Cu}, \mathrm{Zn}$, $\mathrm{As}, \mathrm{Se}, \mathrm{Mo}, \mathrm{Ag}, \mathrm{Sn}, \mathrm{Sb}$, and Bi. Concentration factors suggest urban dusts are extremely contaminated by $\mathrm{Zn}$ and $\mathrm{Cu}$. The ecological risk associated with specific elements decreased in the order $\mathrm{Cd}>\mathrm{Cu}>\mathrm{As}>$ $\mathrm{Hg}>\mathrm{Pb}>\mathrm{Ni}>\mathrm{Co} \approx \mathrm{Zn} \approx \mathrm{Cr}$, and the contamination load index showed that $91 \%$ of the samples are polluted by PTEs. Although the carcinogenic risks of $\mathrm{Cr}, \mathrm{Ni}, \mathrm{As}, \mathrm{Co}$, and $\mathrm{Cd}$ were low, chronic exposure to several PTEs may be impacting the quality of life. Educational programs, as well as monitoring and greater control on traffic, industry, and construction activities, are needed in order to protect environmental and human health.

\section{Keywords}

Cancer, ICP-MS, Manganese, Particulate matter, Zn 